\title{
赤芽球分化に関する研究：多血動物瀉血後 の骨髄赤芽球分化の形態的観察
}

\author{
岡山大学医学部第一病理学教室（指導：妹尾左知丸教授） \\ 中塚 久
}

(昭和54年11月16日受稿)

Key words：多血動物，赤芽球分化

骨髄赤芽球前殹細胞, 末梢血液幹細胞

\begin{abstract}
諸
言

1961年 Till とMcCulloch により開発された脾コ ロニー法及び Becker ${ }^{21} ら の$ 特殊染色体 $\mathrm{T}_{6}$ マーカーを 有するマウスを用いた実験により，血液細胞は単一 のクローンから分化することが証明された。即ち， 彼等は一定数のマウス骨䯣細胞を全身致死照射マウ スの静眽内に移植すると脾に末分化細胞のコロニー ができ，それがやがて赤芽球コロ三ー・顆粒球コ口 ニー・巨核球コロニ一等に分化するのを見た．しか しこれらのコロニーの中には各種の細胞を含む混合 コロニーも認められ，夫々のコロニーは一つの細胞 (Single Cell) から出発することが示された2).これら の実験結果は，血球には共通の幹細胞があって。こ の幹細胞は多分化能を有し，赤芽球・顆粒球・巨核 球・その他の血液細胞に分化することを示し，Maximowの一元論了に有力な支持を与えることになっ た. 更に，この多分化能性幹細胞はコロニ一再移植 の実験から自己複製能を有し，分化に向うことなく 增殖することができることも明らかになった41,5)。周 知の如く、このような多分化能幹細胞に对してマウ 又脾コロニー形成単位 Colony foming unit in Spleen (CFUs) という名前が与えられた。このように, CFUs は多分化能をもつ血球幹細胞であることには 間違いがないが，予期に反してCFUsはサイミジン 自殺実䜽 (tymidine Suicide test)では生きのびるこ とが証明され; CFUs は正常では殆んど DNA 合成 を行わす $\mathrm{Go}$ 又は $\mathrm{G}_{1}$ 期にあることが証明された4。こ れらの事実は, CFUs は各種血球の增殖要求度に応
\end{abstract}

ヒてて夫々の血球を補光する為に細胞周期に入り，赤 芽球・顆粒球・或は巨核球等の前駆細胞 (Comitted Stem Cell), 即 5 Colony forming unit in Culture (CFUc), Erythropoietin responsive cell (ERC), 及 $\mho$ Colony forming unit for megakaryocyte (CFU. $M^{8)}$ 等に分化することを示すものと考之られる。然 し, 脾コロニ一形成実験からも明らかなように，分 化の為には少くとも数日を要することも確かである。 従って, 非常に早く回転している日常の赤芽球・顆 粒球等の産生は, 自己增殖能をもつ $\mathrm{CFU}_{\mathrm{E}} \cdot \mathrm{CFU}_{\mathrm{C}}$ 等によって行われているものと考えられる。

こうして一応幹細胞の新しい概念は生れたが、C$\mathrm{FU}_{\mathrm{s}} \cdot \mathrm{CFU} \cdot \mathrm{ERC}$ 等はどのような形接の細胞なの か, 現在迄に正確な形態学的特徵はつかまえられて いない。

CFUs の赤芽球系細胞への分化は，ERCの投階で 体液因子エリスロポエチン (EP)により誘導されるこ とは明瞭で，ERCは EP の作用で赤芽球に分化する 9,10). ERC の前段階の細胞と考之られる $\mathrm{BFUE}_{\mathrm{E}}$ も $\mathrm{EP}$ で赤芽球に誘導されるが，著しい高瀆度を必要としい， 生理的にEPの作用を受けて分化することは考えられ ない。

筫血で赤血球が不足する場合，或は空気中の $\mathrm{O}_{2}$ が減少して $\mathrm{O}_{2}$ 欠炎を起すような場合には。血中の $\mathrm{EP}$ 湄度が上り赤芽球の增生が起り，逆に多血症で赤血 球が過剩になり充分な $\mathrm{O}_{2}$ が得られる場合には，EP

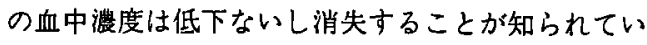
$3^{122}$. 例之ば, 同系動物の赤血球浮遊液を繰返し腹 腔内に輸血することによりへマトクリットが65\%に 
もなった実験的多血症マウスでは、赤芽球の分化が 停止するが、この状態で EP を社射すると，注射後 24時間で前赤芽球が出現し，48時間たつと成熟赤芽 球迄分化するといわれる9".

$\mathrm{EP}$ は又赫芽球の成就分裂をも促進するといわれる13).

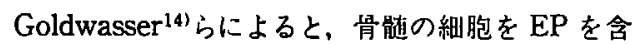
む培者すると 5 分後には浾芽球分化と関係のある $\mathrm{m}$ RNAの合成が起り，2 時間後には DNA 合成が起り， 3 時間後には鉄の捸取， 6 時間後には幼若細胞に一 モグロビン合成がみられる。三浦ら ${ }^{151} の$ 輸血多血症 マウスの骨能を用いた invitoの実験では，EP作用後 4 時間以内に DNA 合成細胞が起り，18 24時間で 赤芽球は最終分化投階まで達すると云う。

以上の実験結果とも関連して，赤芽球の前駆細胞 から形態学的に認識できる最も幼若な赤芽球，即ち 前赤芽球への分化に要する時間については報告者に より又実験方法の相違により著しい差異がある．CFUsからの分化は一応別として，ERCからの分化と 考えられるものについて見ても大動脉吻合パラビオ 一ジス法では42時間16),17，多血動物に EP を注射し た後48時間9!，或は12時間以内14)等と報告されている. このような差異が何に起因するかについては充分明 らかでないが、一つの可能性としては各研究者によ つて少しづつ観察の方法や条件が異るので, ERCの 数が非常に少い時には存在が認識される迄には或程 度の分裂による数の增加を必要とし，比較的長時間 を要する。一方，ERCの数が非常に多い場合には発 見が容易であり、赤芽球が認識される迄に要する時 間が比較的短かく，正確に測定できるのではないか と考えられる。竹林 ${ }^{18}$ は高度の實血家兔に一時に大 量输血し赤血球数を正常に返すると，骨㖪中の赤芽 球が速やかに消失すると共に末梢血赤血球数が 2 ・ 3 日の内に著しい增加を示し,この時点で骨置には 細網細胞梯幼若細胞が充満していると報告している。 これらの細胞は赤芽球への分化が阻止された ERCと 考えられるので，この状態で急激な鴪血を行えば生 体内でERCからの赤芽球への分化に要する時間がか なり正確に把暒できるのではないかと考えられる。 このような考えのもとに著者はラットに一回大量の 演血による高度の費血を起し，これに急激に大量の 輸血を行って Ht を70\%以上の高值とし， 1 週間後 大量滨血を行って赤芽球分化の状態を経時的に観察 した。

このようた状態下では，幼若赤芽球の分化は 6 時 間で誘導され，24時間で全ての分化投階にある赤芽
球を観察することができた。

\section{実験材料及び実験方法}

実駼動物としては，体重280－300gのウィスター 内交系成熟雄ラット75匹を用いた，別に同柔ラット 300匹を供血動物として用いた。

動物は 4 群に分け，第 1 ・第 2 群夫々 5 匹，第 3 群55匹，第 4 群 5 匹とした。第 1 群の 5 匹は筫血動 物とし，第 2 群の 5 匹は第 1 群の貧血動物を急激に 多血状態としたもの，第 3 群の55匹第 2 群と同様の 処置後急激に䳆血したもので，第 4 群の 5 匹は正常 対照動物とした。

第 $1 \cdot 2 \cdot 3$ 群の65匹の動物は 1 回大量演血して, 24 時間後の Ht 值を約 $25 \%$ とした，瀉血は，眼窩後 部の静脈叢にへマトクリット用毛細管を挿入して行 った．第 1 群の動物はこの時点で屠殺した．第 2 ・ 3 群の60匹の動物は, 夫々赤血球生食浮遊液 5-6 $\times 10^{6} / \mathrm{m} \ell$ を 1 回 $7 \mathrm{~m} \ell$ あて腹䐑内に 5 回注射した。即 方初日は 1 日 3 回, 2 日目は 1 日 2 回注射し、3 日 目に Ht 略70\%であることを確認した後1 週間まで 隔日 1 回注射した．第 2 群の 5 匹の動物は輸血開始 後 1 週間で屠殺した，第 3 群の55匹の動物は更に渏 血しながら輸澓及び血清注射を行った，瀉血による 筫血は $\mathrm{Ht}$ 值 $25 \%$ 前後を目標とした。即ち，湶血と 同時に隍菜静脈より生食，5\%グルコース及び健常 ラット血清 1：1：1の割に混じたものを補液した。 瀉血は緩除に行い終了までに約30分を要した。又鴧 血終了後，あらかじめ用意しておいた同系貿血動物 血清約 $6 \mathrm{~m} \ell$ を静脈内に注入した。演血終了後 $3 \cdot 6$ $\cdot 9 \cdot 12 \cdot 18 \cdot 24 \cdot 30 \cdot 36 \cdot 42 \cdot 48$ 及び72時間目に 各々 5 匹の動物を屠殺した．尚第 4 群の動物は無処 置のまま屠殺した，全ての動物は屠殺前に眼窩静脈 洞より採血し，Ht値を測定する一方，1滴を超生体 染色後叙沫標本とし，ギムザ染色を施して網状赤血 球を算定した，全ての動物は屠殺後左側大腿骨を取 出し, 一部叙沫標本とし, 乾燥し、メタノ一儿固定 後メイグリューンワルド・ギムザ染色を施し細胞形的 の観察及び骨骾細胞の分類を行い，残余のものは $10 \%$ フォルマリン固定パラフィン包埋後へマトキシリン ・エオジン染色を施し，骨䯣組織の観察に供した。

輸血用赤血球浮遊液の調整：同系健常動物約 300

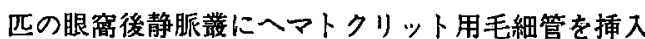
し流出する血液を適量のへパリンナトリウムを含む 水冷生食液中に採った，採取は血液を摫拌しながら 行い凝血を防いだ．採血後2000rpm15分間遠沈し， 
上清を捨て，更に血球成分 2 倍量の生食にて 3 回洗 浄した。血球成分上㕌部の白血球成分は可能な限り ピペットで吸引除去した。 3 回洗净後, 沈下した赤 血球成分に等量の生食を加之赤血球浮遊液とし, 腹 腔内輸血に用いた。

負血動物血清の調整：上記健常内系動物 300 匹の 動物の䳆血 2 日後の血液を採血し, 集めた血液を 1 昼夜静檤し，分離した上清を用いた，尚，採血，血 清採集，輸血時の器具は全て隇菌したものを用いた。

網赤血球 (RC) 算定法 : 0.1\%ブリリアントクレシ ールブルー生理食塩水溶液 1 滴をオブゼクトグラス にとり，末梢血液 1 滴を加えて緗いがラス棒でよく 混和し、望沫、メタノール固定を施した後、ギムザ 染色標本とした，網赤血球は超生染時の姿を再現す

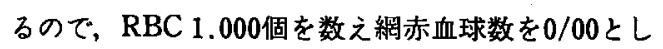
て算出した。

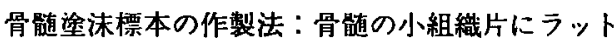
血清 1 滴を加え，2枚のオブゼクトグラスの間に挾 み、静かに加圧して細胞を遊離させたものを叙沫, 乾燥し,メタノールで瞬間固定後, メイグリューン ワルド・ギムザ染色を施した。

骨髄切片標本の作憋：大腿骨を骨鉗子で軽く挾ん で割り, 内部の骨跹組織を取出し, 10\%中性フォル マリンで2 日間固定し, 型の如くパラフィン包埋後, 組織切片標本を作製し，H－E染色を施した。

\section{実 験 結 果}

第 4 群の健常な对照雄ウィスターラット 5 匹、及 U゙全動物の中代意の 5 匹を選んで塞駼開始直前に測 定された $\mathrm{Ht}$ 值は約50\%であり， $\mathrm{RC}$ 数は20\%以下 であった，第 $1 ， 2 ， 3$ 群の70匹の動物では全て前 項で述べた方法で舄血したが，第 1 群の 5 匹につい て測定した結果では，1 回演血を行うと24時間後に は Ht は約25３0\%に低下し， RCは既に約60\% と。 上昇した。この時点で第 1 群の動物 5 匹は屠殺し, 第 2 群第 3 群の動物には赤血球浮遊液を前項で述へ た方法で大量輸血し多血動物とした. 第 2 群の 5 匹 について観察した結果では，輸血の後は Ht は70〜 $75 \%$ となった。第 2 群の動物はこの時点で歷殺した. 第 3 群の55匹の動物には大量の㴼血と輸夜を行い, 多血状悲から30分間で大量䳆血し $\mathrm{Ht}$ 值約 $20 \%$ の貫 血状態にした。これらの動物はこの貧血状態から最 初の12時間までは 3 時間每, その後は 6 時間毎に 5 匹宛屠殺したが，屠殺時に測定した網状赤血球数の 変動を見ると, 淣血 9 時間から $\mathrm{RC}$ が次第に上昇し
12〜18時間で一時停滞、その後は48時間まで略指数 函数的に上昇を示し約 $43 \%$ に至り，その後减少して 72時間後には22\%で略健常動物と同值となった(Fig1). 次に各群の動物の骨跹の塗沫標本, 及び骨髄切片 標本について述へる.

第 1 群の滨血賓血動物の骨跹は赤芽球過形成を示 し赤芽球が骨髄有核全細胞数の $45 \sim 50 \%$ を占め，骨 髓有核細胞全細胞数に対する骨髄赤芽球数比 $\mathrm{E} / \mathrm{T}$ は 高値を示している．組織切片で無処置対照動物 (Fig 2-A)に比し核の濃染する赤芽球群が著明に増加して いるのが認められる (Fig2-B)。この状態で急激に赤 血球輸血を行い多血状態としたものでは，骨葡は赤 芽球が著しく減少し，大型の芽球梯細胞と著明に增 加した顆粒球によって占められている (Fig2-C).

組織切片を強搪大で見ると赤芽球は殆んどなく組 織が顆粒球と大型の細網細胞栏細胞で核の好塩基性 が弱い細胞で占められ，他の組織と比較すると全体 として非常に染色状態がわるいように見える (Fig2C,D)。骨髄叙沫標本で見るとこれらの細胞はリンパ 芽球ないし細網細胞樣形態を呈する (Fig2-E, F,G). このような骨䰙をもつ多血動物を大量演血し経時的 に観察すると，漆血後 3 時間目に既に大型で細胞質 がやや好塩基性に染まる前赤芽球が出現する (Fig-2H). 湯血後 6 時間の組織切片では，これら大型の前 赤芽球と思われる幼若細胞が僅かながら集蔟を形成 して增殖してているのがみられる (Fig2-I). この時点で 成熟型赤芽球数の增加も明暸である (Fig3)，演血後 9 時間から12時間を経過すると組織切片では 6 時間 ないし 9 時間で比較的明瞭であった赤芽球集蔟が, 明瞭に認められるようになり (Fig2-J)，E/T比の增 大が顕著である (Fig3). 涂沫標本では前赤芽球及び 好塩基性赤芽球と明瞭に認められる細胞が增加する (Fig2-K). 滨血後12時間で赤芽球数は一過性に減少 する (Fig3)。湶血後18時間で $\mathrm{E} / \mathrm{T}$ 值は再度上年の傾 向を示し (Fig3)．24時間を経過すると骨䯣叙洙標本 では，增加した好壏基性赤芽球及び以降の分化投階 にある赤芽球系細胞が目立つようになり (Fig2-L, M, Fig3)，組織切片では赤芽球集蔟は更に増加している のが認められる (Fig2-N). 䳆血後36時間まで赤芽球 比は増加するが, 特に好塩基性赤芽球数の増加が顕 著である．その後 $\mathrm{E} / \mathrm{T}$ 比は增減したがら，成就型赤 芽球の增加が主体となり72時間までに健常動物の骨 檤像に類似した所見を示すようになる (Fig3，Fig2O). Fig3は骨蹃の赤芽球対骨跹全有核細胞比及び赤 芽球分類をまとめて示したものである．第 4 群の健 


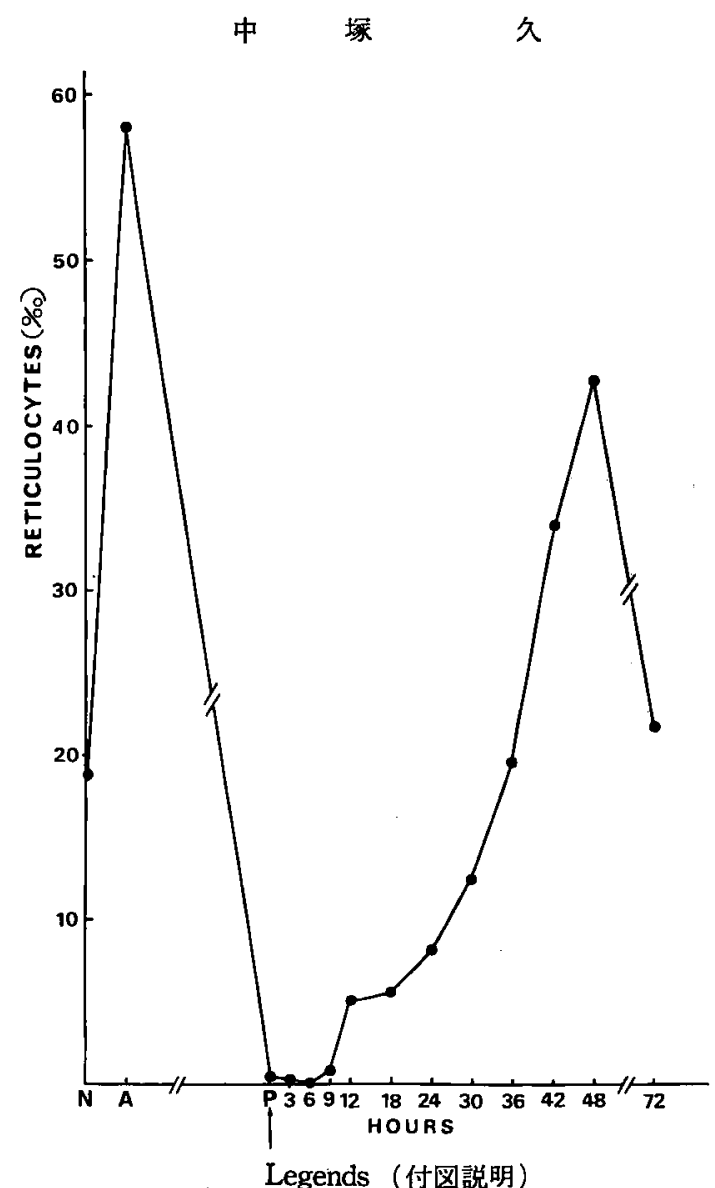

Fig. 1 Reticulocyte number in peripheral blood under nor-

mal, anemia and polycythemia, and anemic condi-

tions after blood withdrawal. N; normal, A; anemia,

$\mathrm{P}$; polycythemia, $\uparrow$; Blood drawing.

Fig. 2 Cytohistologic pictures of bone marrow sections and smears. A; Normal bone marrow, 10x10. B; Bone marrow of an anemic animal with erythroid hyperplasia. $10 \times 10 . \mathrm{C}$; Bone marrow of a polycythemic rat showing myeloid marrow, 10x10. D; Enlarged picture of bone marrow of a polycythemic animal and shows reticulum cell-like cells having clear cytoplasm and a big nucleolus. 10x40. E-G;Smears from a polycythemic animals. Lymphoblastoid or reticulum cell-like cells appeared in bone marrow. 10x100. H; Proerythroblast like cell appeared 3 hours after blood withdrawal. 10x100. I; Bone marrow section 3 hours after blood withdrawal showing small erythroid cell clusters composed of primitive erythroid cells. 10x20. J; Bone marrow section 6 hours after blood letting. The erythroid clusters became prominent and increased in number with some mature ones. $10 \times 20$. K; A proerythroblasts having characteristic cytoplasmic basophilia and nuclear chromatin nets appeares 6 hours after blood letting. 10x100. L; An early basophilic erythroblasts having deep basophilic cytoplasm and matured erythroblasts seen 12 hours atter blood withdrawal. $10 \times 100$. M; Three matured erythroblasts being associated with a macrophage seen in the same field of smear as L. $10 \times 100$. N; Bone marrow section 12 hours after blood letting showing eyrthroid clusters. 10x20. 0 ; Bone marrow section 72 hours after blood letting and shows the picture of erythropoiesis returned to normal. $10 \times 10$. 
中塚 久論文附図

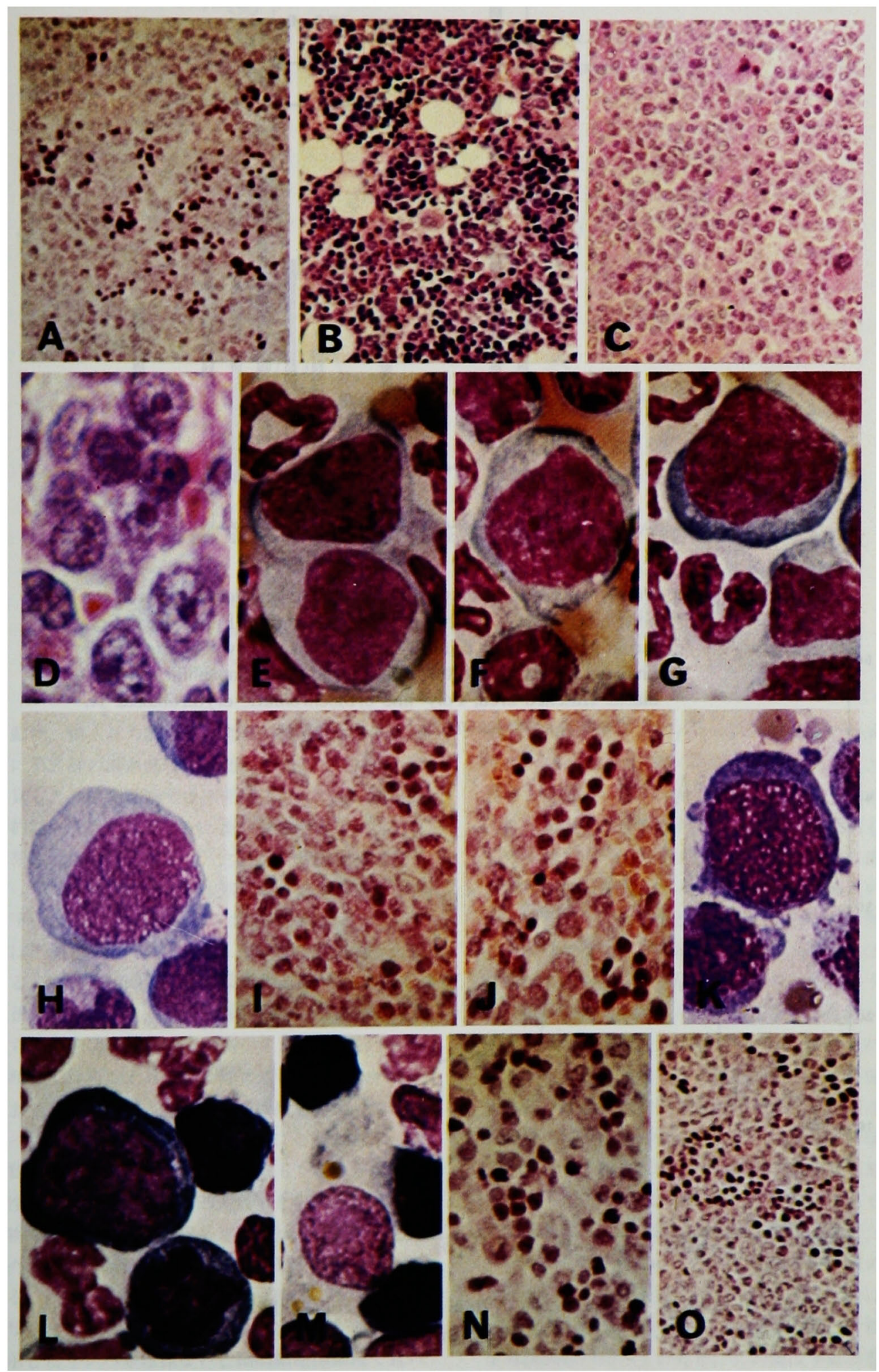




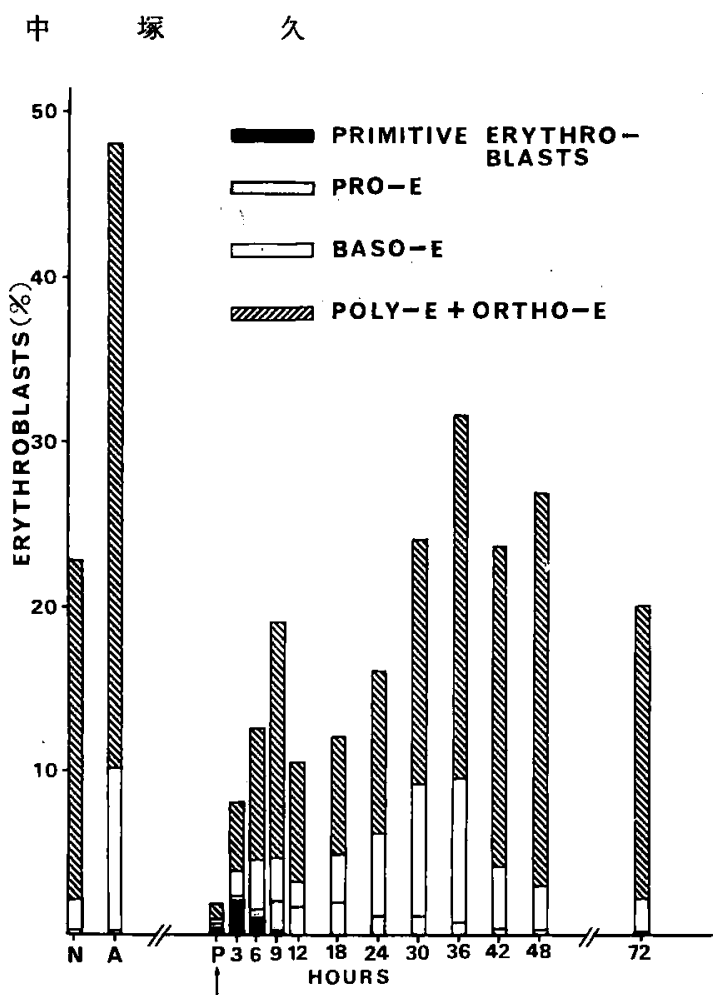

Fig. 3 Numerical ratios of erythrois cells to total nucleated cells in the bone marrow with erythroid cell classification. Filled area; Erythroid precursors or primitive erythroblasts shown in Fig 2E-H. Shadowed area; Proerythroblasts. Open area; Basophilic erythroblasts. Hatched area; Poly- and orthochromatic erythroblasts. N, A, P and $\uparrow$; See legend in Fig 1.

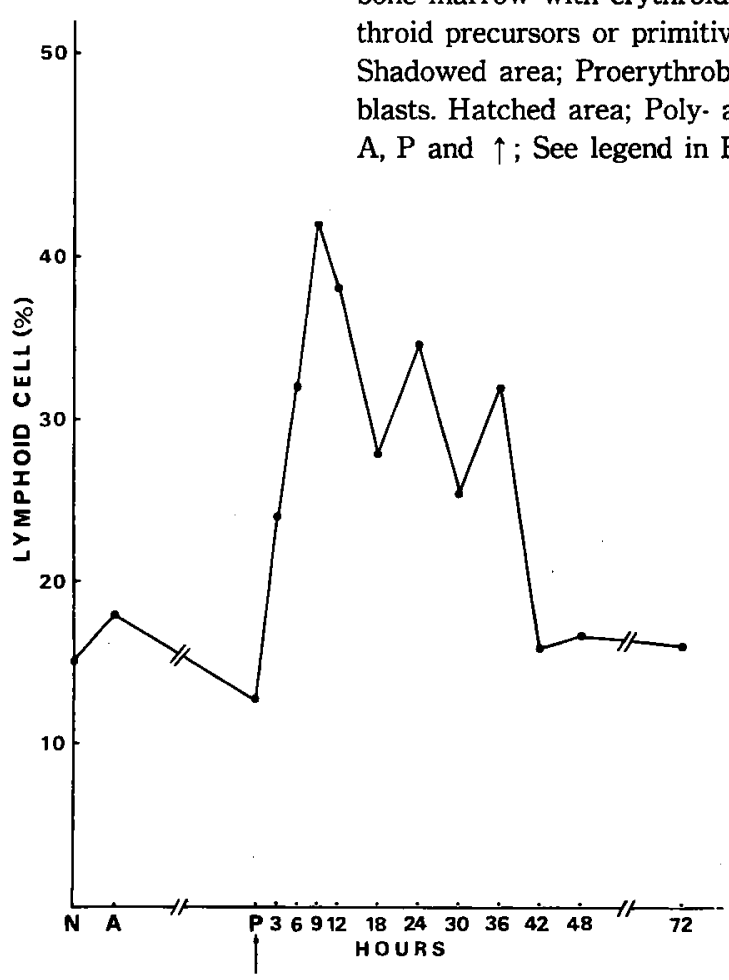

Fig. 4 Numerical ratios of lymphoid cells to total nuclexated cells in the bone marrow. N, A, P and $\uparrow$; See legend in Fig 1 . 


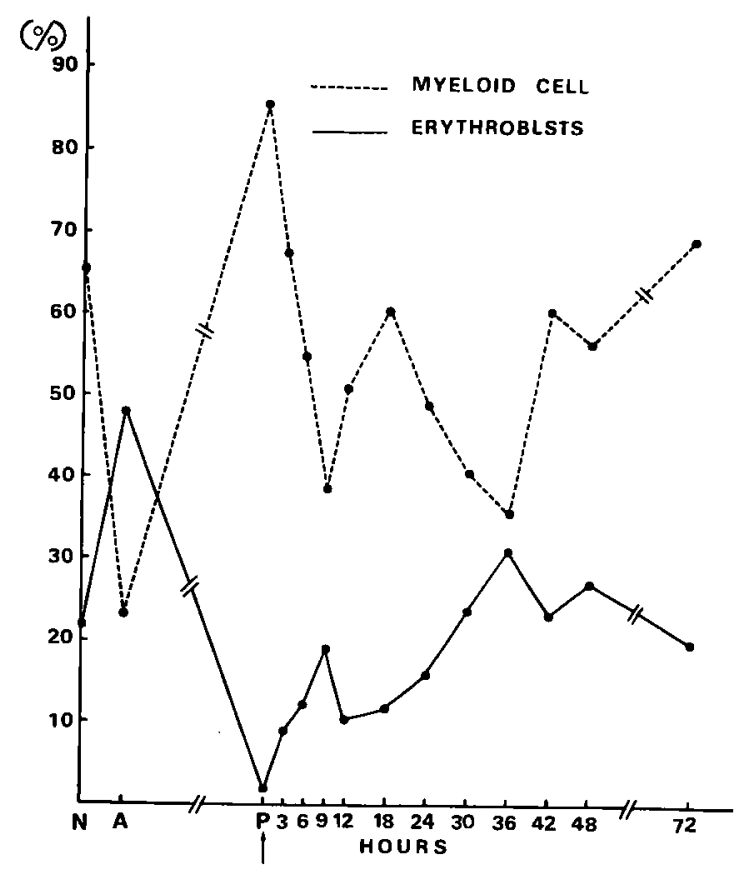

Fig. 5 Erythroid and myeloid cell number under normal, anemia and polycythemia, and anemic conditions after blood witthdrawal. N, A, P and $\uparrow$; See legeng in Fig 1.

常動物，第 1 群の滨血貟血動物、第 2 群の多血動物、 更に第 3 群の䵘血動物の時間的な骨髄赫芽球の動態 を見ると，健常動物では赤芽球は骨㵦全有核細胞数 の約 $22 \%$ 占めているが，瀉血貟血動物においては 赤芽球数は著しく増加し，これに大量赤血球輸血を 行って多血状態にすると 1 週間目には赤芽球は $2 \%$ 以下となる。この多血動物では，演血後速やかに $\mathrm{E} / \mathrm{T}$ 比は增加し， 6 時間で13\%，9時間では約18\%に達 する。その後12時間でやや減少する傾向を示すが, 以後増加してゆき，36時間後には32\%に達する。 れら赤芽球は 42 時間でやや減少する傾向を示すが, 48時間では再度上景，72時間までに健常動物のレべ ルまでもどる.この赤牙球数の增減を分化の投階に よって分類してみると次のようなことがかかる. 即 ち䨘血動物では前赤芽球は $1 \%$ 以下で好塩基性，多 染性及び正染性赤芽球が $99 \%$ 以下を占めるが，多血 動物では前赤芽球，好塭基芽球が殆んど見当らず, 極めて少数の多染性及び正染性赤芽球を見るのみで ある. 尚, 多血動物及び瀉血後 3 時間で前赤芽球と 分類されているものは形態的に Fig2-E，F並びに G に示したリンパ芽球様ないし細網細胞様細胞で真の
前赤芽球は殆んど見られない，多血動物で特異なこ とはこれら大型のリンパ牙球ないし細網細胞と呼ば れうる細胞 (Fig 2-E - G)が全体の $25 \%$ 以上を占め, これを前赤芽球とみなせば健常動物の約15倍も増加 しているということである。これらの細胞は演血 6 時間後には激減し，この時点で前赤芽球類以の細胞 (Fig2-H) 並びに前赤芽球が出現し早期好塩基性赤芽 球への分化傾向がみられる。濆血後 9 時間では前赤 芽球は少し增加し，多染性赤芽球への分化がうかが われる。瀉血後12時間たつと好塩基性赤呀球が一過 性に減少し多染性及び正染性赤芽球への分化が明瞭 となり，24時間経過すると36時間まで前赤芽球の減 少に伴い晚期好塩基性赤芽球の著增と多染性赤芽球, 正染性赤芽球の增加が見られる，以後前赤芽球は漸 減しE/T比の增加に伴い多染性及び正染性赤芽の増 加がみられ， $\mathrm{E} / \mathrm{T}$ 比は增減を示すが72時間までに全 てが健常動物の赤芽球造血の像に等しくなる。

赤芽球以外の細胞としては, 骨蹎リンハ球の分布 は非常に特異的である(Fig 4)，ラットは末血にリン 八球が多く健常動物で約60〜70\%を占め, 骨涟でも 全有核細胞の15\%を占める，この值は多血状態でも 
殆んど変化がない $(17 \%)$ 。然し瀉血後增加し瀉血 3 時間後には $24 \%$ に増加し，9時間後には $41 \%$ と著明 に增加する．その後18時間まで減少し，以後は12時 間毎に増減をくり返し，72時間までに健常動物と同 値となる。

顆粒球数は赤芽球の動きと逆向に動く傾向を示す (Fig 5). 即ち, 多血動物では顆粒球髄を呈するが, 誼血後赤芽球の增加に伴い減少し, 以後赤芽球の堌 減に伴って逆相関的に動く.

\section{考案}

本実験は, エリスロポエチン反応細胞(ERC)の分 化が，生体が賽血状態に陷った場合に，どの程度の 時間で赤芽球に分化するかを知る目的で行ったもの である。この奉験系で著者は骨髄内 ERC の数が著 しく增加していると考えられる漆血實血後大量輸血 による多血状態から，更に急激な瀉血を行って一定 時間々隔で骨檤の検索を行った，上記奏験結果から 見られるように，多血状態で赤芽球分化が一時的に 停止したラット骨髄では赤芽球前駆細胞から前赤芽 球への分化は既に 3ー6 時間までに起り(Fig2-H,I), 9 時間までに好塩基性赤芽球及び多染性赤芽球まで 分化して (Fig2-J, K, Fig3)，12時間までに第 1 相の 赤芽球分化が終了する。これは多血状態で一時分化 を止めていたか或いは分化が紱徐となっていた赤牙 球前駆細胞が滨血及び EP に相当する賓血動物血清 注射により刺激されて速やかに赤芽球に分化したも のと考えられ，これら前駆細胞は ERC の中でも福 めて前赤牙球に近い投階のものと考えられる。この

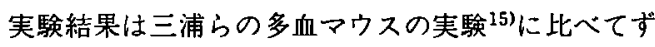
いふん赤芽球分化が速いようであるが，飢餓ラット 骨骨有細胞に EP 添加後 5 分以内に PNA 合成が始ま り 2 時間後には DNA合成が起り，3時間後には鉄 捸取， 6 時間後には幼若赤芽球にへモグロビン合成 がみられ，12時間たつと最後成熟投階の赤芽球が見 られたという Goldwasser ら ${ }^{14)}$ の報告とよく一致する。

急激な䵘血によって前赤芽球によって前赤芽球に 分化する $\mathrm{ERC}$ がどのような形態の細胞であるかは

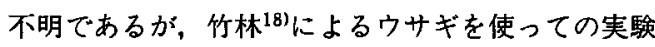
では，瀉血賽血動物に同系赤血球を大量に注入して 正常の赤血球数にすると, その後 $2-3$ 日間末血の 赤血球は増加し続け，増加が停止した状態では，骨 髄にに殆んど赤芽球がなく細網細脆様幼若細胞が立 満していた。この実験は，䏝血により大量に産生さ れた赤牙球は，急激な輸血によって不用になっても
赤血球に分化し，ERCの投階でフィードバックがか かっていることを示すようにみえる，少くとも一部

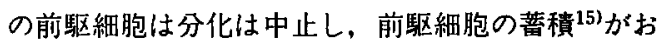
こることが期待される。

本実験では，ラットに於て竹林のウサギに於ける 実験と類似の実験をラットで繰返したもので，この 多血ラットの骨髄でも赤芽球数極めて少なく(Fig 3), 少数の成熟赤芽球を見るのみで，一見顆粒球髄の状 態を呈しているが，いわゆる大型の細胞様細胞で核 の淡染する細胞が増加している(Fig 2-C, D).こ れらの細胞は塗沫標本では好塩基性大型のリンパ芽 球ないしいわゆる細網細胞に類似した細胞で(Fig2-E $\mathrm{E} \sim \mathrm{G})$ ，約 $40 \%$ を占めており，好塩基性赤芽球は極 めて少い(Fig 3). 瀉血 3 時間ではこれら芽球は前赤 牙球類似の形態をとり全赤牙球の約 $1 / 3$ 占め渴血 後 6 時間では明らかに前赤芽球好塩基性赤芽球への 分化が見られ多染性赤芽球への分化傾向を示し，9 時間後には第 1 相の赤芽球分化が終了する(Fig3). 瀉血後 3 時間では $\mathrm{E} / \mathrm{T}$ 比は多血動物の約 3 倍にも増 加し牙球も約 3 倍となっている，一部の前駆細胞は 分裂期に入っているものと考えられる，ERCでも種 々の投階の細胞があるので19)この時点で芽球増加に 関与している細胞は極めて前赤球に近い分化投階の ものと考えられる。即ち大型の細網細胞様細胞ない しリンパ芽球様細胞 (Fig2-D〜G) が ERC に相当す る可能性が多分にありこれらの細胞自体少しづつ分 化投階を異にしている可能性がある。

妹尾ら 20 はかつて急性リンパ性白血病の細胞が組 織に浸潤して増殖するとき細網細胞様の形態をとる ことを見出したがここれはンパ腺の胚中心に存在 する細胞の形態に一致し，天野氏の Lymphogonia に相当するものかも知れない，リンハ球は既に芽球 化現象が知られている21). 従って赤芽球に於いても， その前駆細胞が細網細胞様形態を示しても特殊な現 象ではたいように思われる，前述の如くGoldwass$\mathrm{er}^{14)}$ によれば，EP 添加後培養ラット骨鲔では 5 分 以内に RNA 合成が起り，2 時間で DNA 合成， 6 時間ではへモグロビン合成がみられることが認めら れている. 著者の実験でも瀉血後 6 時間で前赤芽球 の分化を認めているので，ERCからの赤芽球の分化 は意外に速く起るものと考えてよいようであろう。 瀉血 6 ～9 時間後には $\mathrm{E} / \mathrm{T}$ 比は顕著な上昇を示し, 形態学的にも好塩基性赤牙球の分化が顕著であるこ とを見れば，この時点で，既に前赤芽球が旺んに細 胞分裂を行い分化していることが示焧される(Fig3). 
この間少数の成熟赤芽球が見られるが，これは多血 状態で尚且分化していた少数の芽球から来たものと 考えられる，E/T比は 9 時間で著明に大きくなり 12 時間では一過性に低下するが，この理由については 多血状態で一部Synchronize されていた ERCない し赤来球前駆細胞が分化しきって，後続の前駆細胞 が末だ赤芽球に分化していない状態かと考之られる。 この時点までの一連の $\mathrm{E} / \mathrm{T}$ 比及び赤芽球分類の変動 は ERCにも種々の分化投階があることを示唆する ものと考えられる。

雌雄パラビオージスラットによる実験からすれば, 末梢血有核細胞が大巾に赤犽球産生に関与している

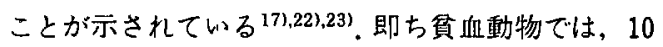
日間で40\%近くの分裂細胞が未悄血から骨䯣に流入， 増殖していることが示されている．末梢血中を流れ ている前駆細胞の形態は不明であるが、実呀結果は 少くとも次のことを示している，即ち，赤芽球造血 は骨髄内の細胞のみで行われるのではなく、末梢か らの細胞の分裂と分化により大きく支之られている と云うことである.著者の実験で演血後 9 時間迄の $\mathrm{E} / \mathrm{T}$ 比の増加と，12時間における一過性の增加の低 下，更にその後の加速的增加様式が 2 相性を示して いるのは，前者は骨髄内に残存した赤芽球前駆紲胞 の分化と分裂を示し, 次の相は末血由来の前駆細胞 の関与を示唆しているのかも知れない. 少くとも末 梢血には細網細胞様幼若細胞は存在せず，成熟型の 細胞であるから，これらが芽球化する為に一定の時 間を必要とすることは当然考えられる。

$\mathrm{X}$ 線致死照射ラットを大動脈吻合パラビオージス によって正常非照射動物と結合した奏験では，末梢 血中の有核細胞が骨髄に定着し，前赤芽球に分化す るのに要する時間は最短 42 時間とされており，48時

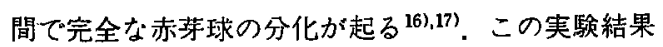
に比へ，本実験では赤芽球の分化はかなり促進され ているように見えるが，X線照射状態と云う異常な 細胞環境の中での分化は正常状態よりはるかに痋れ るのかも知れない。

最後に ERCの形態について考察を加えたい，貝 血から急激に多血状態に移した動物の骨䯣に見られ る細網細胞樣細胞が ERC の一つの形である可態性 については既に述べた，然し，未梢血有核細胞につ いては，その形態は今の所全く不明である.Van Bekkum ${ }^{24)}$ は、CFUs の細胞形態を骨髄細胞を分画法 によって各種細胞種に分けて追及し、リンハ球様細 胞であろうとして，その形態を詳しく記載している
が, 彼の得た分画は少数ながらリンパ球以外の細胞 毛含まれている。本研究における骨㩆でのリンハ球 の動態を見ると演血後著明に増加を続け，9時間で ピークに達し18時間まで減少する。その後は略12時 間の間隔で增減をくり返し，42時間後は略健常動物 と同分布を示す (Fig4)。この滨血初期における骨蹎 でのリンパ球分布の急激な增加傾向, 及び高值を保 ちながら12時間毎に增減するパターンは，骨髄りン ハ球様細胞が赤芽球前駆細胞として働いている可能 性を示惨しているように思われる。確実な証明は

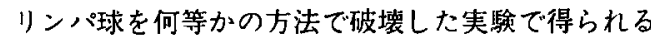
かも知れないか，今後の研究に俟たれる所である。

\section{結語}

赤芽球前駆細胞ーエリスロポエチン感受性細胞(E$\mathrm{RC)}$ に相当する細胞一がどのような動態をとり赤第 球に分化してゆくかについて観察した。実験は 1 回 㵻血して赤芽球分化を促進させたラットに，急激に 大量輸血を行い多血状態とし，約 1 週間を経過した 後 1 回大量瀉血後，経時的に骨髄での赤芽球分化の 動態を形態学的に追及した。

観察結果をまとめると次のようである。

1) $\mathrm{Ht} 25 \%$ 前後の高度の䵘血貟血のラットでは骨髄 は赤芽球過形成を示す（赤芽球(E)／全骨蹎有核細 胞 $(\mathrm{T}) \fallingdotseq 50 \%$ ).

2 )このような動物に同系動物の赤血球を注入して 短時間内に多血状態 $(\mathrm{Ht} \fallingdotseq 70$-75) とすると，1 週間後には顆粒球䯣となり，赤芽球数は著しく減

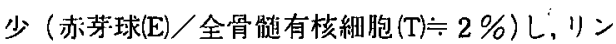
八芽球様ないし細網細胞様細胞が目立つ。こか 前駆細胞から赤芽球への分化が抑制さされた時の骨 骹形態学的表現である。

3)この状態で大量の瀉血を行いな゙がら循環液量を 保つため同時に輸液（生食：血清=1：1）を行 つて約 30 分でHt 值約 $25 \%$ の極端な貫血状態におく と急激に赤芽球の分化が誘導される。

4 ）時間的に骨䯙に起る変化を観察した結果では, 䳆血後 3 時間で前赤芽球の分化が起り始め： 6 時 間では早期好塩基性赤芽球への分化がみられ，9 時間までに正染性赤芽球まで分化する。これが多 血状態で一時停止していた赤芽球前駆細胞よりの 分化相である．その後 $\mathrm{E} / \mathrm{T}$ 值は一度低下し36時間 まで增加を続ける。これが末血由来の赤芽球前駆 細胞よりの分化相である。このように赤芽球前駆 細胞は 2 相性を示す. 42 時間以後は分化と增殖を 
くり返しながら72時間までに略健常動物と同值を 示す.

5 ）末梢網状赤血球数は瀉血 9 時間後より增加し始 め12ー18時間で一時停滞するが，以後急激に上昇 して48時間で40\% 以上に達し，72時間で健常動物 と同值となる。

6 ）骨髄細胞の分類では赤芽球の增加に先立ってり ン八球様細胞ないし細網細胞様細胞の增加が起り， 幼若赤芽球は一定の消長を続けながら赤芽球增生 の期間中継続する．顆粒球系細胞は赤芽球・リン 八球系細胞の增減に対し相補的な傾向をもって変
動した。

7 ）以上の実験結果から，骨髄中での赤芽球の分化， 及び末悄血有核細胞からの赤芽球への分化の動態 について考察を加えた。

\section{謝辟}

稿を終るにあたりまして御指導，後校閲下さいました 妹尾左知丸教授，終始御指導、御教示賜りました林朢辉 講師亚びに薛昭亮助手に深謝致します. (本論文の要旨は第39回日本血液学会総会に於いて発表 した).

\section{女 献}

1) Till, J. and Mc Culloch, E.A.: A direct measurement of the radiation sensitivity of normal mouse bone marrow cells. Radiat. Res. 14, 213, 1961.

2 ) Becker, A.J., Mc Culloch, E.A. and Till, J.E.: Cytological demonstration of the clonal nature of spleen colonies derived from transplanted mouse marrow cells. Nature 197, 452, 1963.

3 ) 天野重安：血液学の基磯(上券).8 頁，丸善出版株式会社，1948年。より引用。

4. Becker, A.J., Mc Culloch, E.A., Sinovitch, E.A., Sinovitch, L.I. and Till, J.E.: The effect of differing demands for blood cell production on DNA synthesis by hemopeietic colony-forming cells of mice. Blood, 26, 296, 1965.

5 . Lewis, J.P. and Trobaugh, F.E. Jr.: Haematopoietic stem cells. Nature 204, 589, 1964.

6. Ichikawa, Y., Pluznick, D.N. and Sachs, L.: In vitro control or the developement of macrophage and granulocyte colonies. Proc. Natl. Sci. U.S.A. 56, 488, 1966.

7. Kranz, S.B., Gallien-Lartigue, O. and Goldwasser, E.: The effect of erythropoietin upon heme synthesis by marrow cells in vitro. J. BIol. Chem. 238, 4085, 1963.

8. Metcalf, D., Mc Donald, H.R., Odartchenko, N. and Sordat, B.: Growth of mouse megakaryocyte colonies in vitro. Proc. Natl. Acad. Sci. U.S.A. 72, 1744, 1975.

9. Nakao, K., Miura, Y. and Takaku, F.: In vitro effect of erythropoietin on the spleen of the polycythemic mouse, I. Blood 27, 646, 1966.

10. Miura, Y., Mizoguchi, H., Takaku, F. and Nakao, K.: In vitro effect of erythropoietin on the spleen of the polycythemic mouse, III Limitted exposure to erythropoietin and actinomycin D. Blood 31 , $433,1968$.

11. Iscove, N.N.: Comparison of human and mouse erythroid progenitors detected by colony formation in culture, In Erythropoiesis ed. K. Nakao, Univ. of Tokyo Press, p. 115, 1975.

12. Balcerzak, S.P. and Bromberg, P. A.: Secondary polycythemia. Semin. Hematol. 12, 353, 1975.

13. Krantz, S.B. and Jacobson, L.O.: Erythropoietin and the Regulation of Erythropoiesis, The University of Chicago Press, Chicago and London, pp. 128-132, 1970.

14. Goldwasser, E.: Some molecular aspects of red cell differentiation, Regulation of Erythropoiesis, ed. A.S. Gordon M. Condorelli and C. Peschle, Ponte, Milano, P. 227, 1972.

15. 三浦恭定：赤血球の細胞周期，日本動物学会編 “細胞周期”，171頁, 東大出版会, 1976年.

16. Seno, S., Fang, C.H. Himei, S. Hseh, C. L. and Nakashima, Y.: Hemopoietic recovery in bone marrow of lethally irradiated rats following parabiosis. I. Granulopoiesis.: Acta Haematol. 55, 321, 1976. 


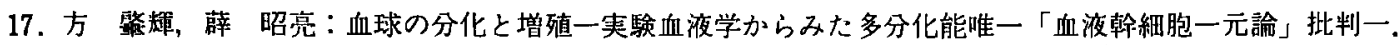
倉数中央病院年報, $47: 73,1978$.

18. Takebayashi, J.: Effect of mass blood-transfusion on erythroid cell differentiation in anemic rabbit I. An evolutional change in the cell specialization process. Acta Med. Okayama 21, 251, 1967.

19. 三浦恭定：血液幹細胞，22頁，中外医学社，1977年。

20. 姝尾左知丸，小林淳一，木村三雄，久保融，川野善彦，佐々木邦朗，藤田公朗：白血病性網内症の 1 例に ついて, 白血会誌, 21, 145, 1958 .

21. Nowell, P.C.: Phytohemagglutinin; an initiation of mitosis in cultures of normal leuukocytes Cancer Res. 20, 462, 1960.

22. Shimada, K.: Chimeric analysis of hemopoietic cells after cross-sex parabiosis. Acta Med. Okayama 29, 189, 1975.

23. Yamashita, S., Baba, Y., Fang, C.H.-Hayashi, Hsueh, C.H. and Seno, S.: Participation of circulating nucleated cells in hemopoiesis observed by chimerism. Society. of Hematology, IV-Meeting of AsianPacific Division. of Hematology, Seoul. 1979.

24, Van Bekkum, D.W., Van Noors, M.J., Mast, B. and Dicke, K.A.: Attempt at identification of hemopoietic stem cell in mouse. Blood, 38, 547, 1971. 


\section{Induction of erythroblasts in polycythemic rat bone marrow after acute blood letting Hisashi Nakatsuka \\ Department of Pathology, Okayama University Medical School, Okayama, Japan}

(Director : Prof. S. Seno)

Wistar rats were made polycythemic by daily injections of massive numbers of red cells for one week. The injections were made into the peritoneal cavity and the $\mathrm{Ht}$ level rose to between 70 and $75 \%$. This plethoric state resulted in suppressed erythropoiesis of the bone marrow. At this stage, a quantity of blood was drawn from the orbital sinuses with concomitant transfusion of a saline-glucose-blood serum mixture. This withdrawal-transfusion process took about 30 minutes and the $\mathrm{Ht}$ value decreased from 75 to $25 \%$. Distinct proliferation of erythroblasts and basophilic erythroblasts was observed 6 to 9 hours after blood withdrawal. Polycythemic animals had many large blast-like cells having relatively large clear cytoplasm. In each of these cells, the nucleus had fine chromatin nets and an ambiguous nucleolus. At 3 hours after blood withdrawal proerythroblast like cells with basophilic cytoplasm had appeared, but there were no basophilic erythroblasts. Typical proerythroblasts having characteristic nuclear chromatin nets and deep blue cytoplasm were prominent after 6 to 9 hours. More mature, poly- and orthochromatic erythroblasts appeared between 9 and 12 hours after blood letting. At 72 hours after blood letting, the cytohistologic picture of the bone marrow of polycythemic animals had returned to nearly normal. Possible erythroid cell differentiation from precursors in the bone marrow and from circulating blood is discussed. 